Bisset, K. A. \& HAle, C. M. F. (1951). J. gen. Microbiol. 5, 150-154.

\title{
The Development of Bacterial Flagella in the Germinating Microcyst
}

\author{
By K. A. BISSET and C. M. F. HALE \\ Department of Bacteriology, University of Birmingham
}

\begin{abstract}
SUMMARY: The microcyst stage of Salmonella typhi, Proteus vulgaris, Bacterium coli and Pseudomonas fluorescens is non-motile and devoid of flagella. Observations by electron- and photomicroscopy indicate that the flagella grow outwards through the cell wall of the germinating microcyst. They commence to develop after about $2 \mathrm{hr}$. incubation. Alike in bacteria with peritrichous and polar flagella a single, polar or sub-polar flagellum develops first. In the process of maturation the flagella are shed and the non-motile microcysts produced. Basal granules may occasionally be observed.
\end{abstract}

In recent years there has been some controversy about the nature of bacterial flagella, centring upon the work of Pijper (1946), which was discussed in the recent Symposium (1949) on 'the nature of the bacterial surface' held by this Society, and which need not be further reviewed here. The present study shows that bacterial flagella grow outwards through the cell wall of the developing microcyst, and that their development follows a regular pattern.

\section{METHODS}

Inocula, made from cultures of Salmonella typhi, Proteus vulgaris, Bacterium coli and Pseudomonas fluorescens, appeared microscopically to be composed mainly of microcysts (Bisset, 1950 $a, b$ ), and were entirely non-motile. Various strains took from 2 or 3 days to several weeks to achieve this condition. Inocula were washed in saline and centrifuged to free them from loose flagella derived from the previous, vegetative generation. Cultures were made on nutrient agar, and from these, preparations were made at various periods after inoculation. Preparations were stained by a variety of 'flagellar impregnation' stains, of which mordanting with a solution of $7 \%$ tannic acid and $0.5 \%$ ferric chloride, before heating with Hortega's silver solution, was found to be most satisfactory. Preparations were also examined with the electron microscope. These were shadowed with metallic gold at an angle of 45 degrees. Lower angles gave greater apparent clarity of image, but obscured details in the margins of the bacteria. Motility was examined in hanging drops.

\section{OBSERVATIONS}

Germinating microcysts. Mature microcysts, before germination, were entirely devoid of flagella (Pl. 1, fig. 1). Motility began to develop at about $2 \mathrm{hr}$. incubation at $37^{\circ}$ and bacteria from these cultures showed all stages of development of flagella. Some just pierced the cell wall (Pl. 1, figs. 2-5; Figs. 1, 2). In some cases the emergent flagella appeared to push the cell wall outward, forming a collar around the base of the flagellum. In Salm. typhi, Pr. vulgaris 
and Bact. coli the first to appear were polar or sub-polar, and almost always the remaining flagella developed most rapidly in the region of this pole. There is evidence that the main growth of the cell was from the opposite pole (Bisset, 1951) (Pl. 1, fig. 3, and Pl. 2, figs. 6-10). The flagella of Ps. fluorescens were exclusively polar or sub-polar in position, but here also one usually emerged well in advance of the remainder (Pl. 2, fig. 11, and Pl. 3, figs. 12-15). After a short time, in all these species, some flagella could be observed to be fully grown, while others were in various stages of growth (Pl. 3, figs. 16-20), and in the case of $P s$. fluorescens they occasionally began to appear at the opposite pole also, well in advance of their normal appearance at cell division (Bisset, 1951) (Pl. 3, figs. 21, 22, and Pl. 4, fig. 23). Mature bacteria, with their full quota of flagella, were common in cultures aged $4 \mathrm{hr}$. and more. In Salm. typhi they were regularly ten in number, distributed evenly along the sides of the bacterium, rather towards one pole; those of Ps. fluorescens were four or five in number, in a tuft at one pole; those of $\boldsymbol{P r}$. vulgaris were more variable, and often were exceedingly numerous (Pl. 4, figs. 24-26).

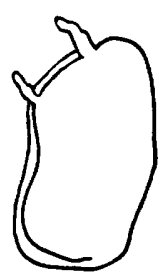

Fig. 1

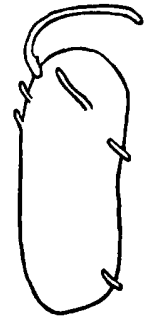

Fig. 2

Fig. 1. Tracing of germinating microcyst of Proteus.

Fig. 2. Tracing of germinating microcyst of Sal. typhi.

Older cultures. Cultures more than 2 or 3 days old, the exact age depending upon the strain, began to contain bacteria in process of maturation into microcysts. During this process the flagella were shed, and in preparations from such cultures, large numbers of broken, cast-off flagella could be seen (Pl. 4, fig. 27). These could be removed entirely by washing and centrifuging.

Basal granules. Occasional electron micrographs of germinating microcysts showed granular structures at the base of the flagella (Pl. 1, fig. 5), and one partially disrupted cell of Ps. fuorescens showed these basal granules or blepharoplasts very clearly (Pl. 4, fig. 28).

\section{DISCUSSION}

The observation that the resting cells or microcysts of motile bacteria are nonmotile and devoid of flagella provides a starting-point for the examination of the development of the flagella. They begin to appear after about $2 \mathrm{hr}$. incubation of mature microcysts when these are subcultured upon fresh medium. The pattern of development is surprisingly regular (Fig. 3). Almost always the polar flagella develop before the remainder. Partly-grown flagella often appear, 
in electron micrographs, to have a collar around the base. This may be an artefact, but as it is common in half-grown flagella, and rare when they are fully developed, it may be due to mechanical pushing outwards of the cell wall by the growing flagellum, or may even be a structure concerned with the
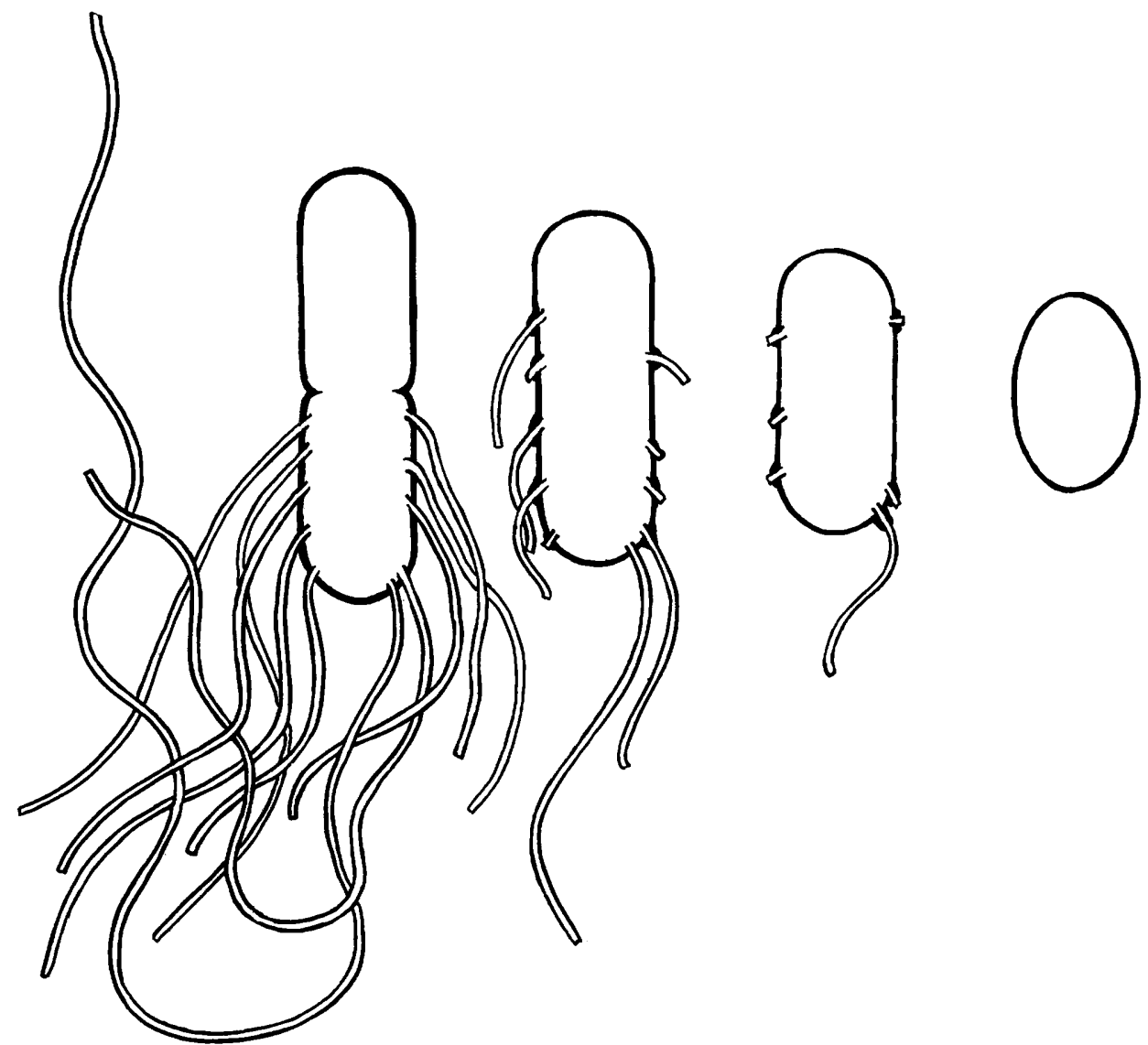

Fig. 3. Development of the flagella upon the germinating microcyst of Sal. typhi.

secretion of the flagellum. When the vegetative bacterium matures into a microcyst the flagella are cast off, and may break up into short pieces. The existence of the bacterial blepharoplast, described by Houwink \& van Iterson (1950), is confirmed.

All these points indicate that the flagella are organs, produced within the cell wall and growing outwards through it, and that their arrangement and development are regular and characteristic. The observations of Pijper (1946) that the flagella may become twisted into a polar whip, visible by dark-ground illumination, are perfectly compatible with these conclusions, but Pijper's hypothesis that the flagella are threads of mucus, drawn out from the slime layer of the bacteria, is utterly at variance with the evidence presented in this paper. 
Journal of General Microbiology, Vol. 5, No. 1
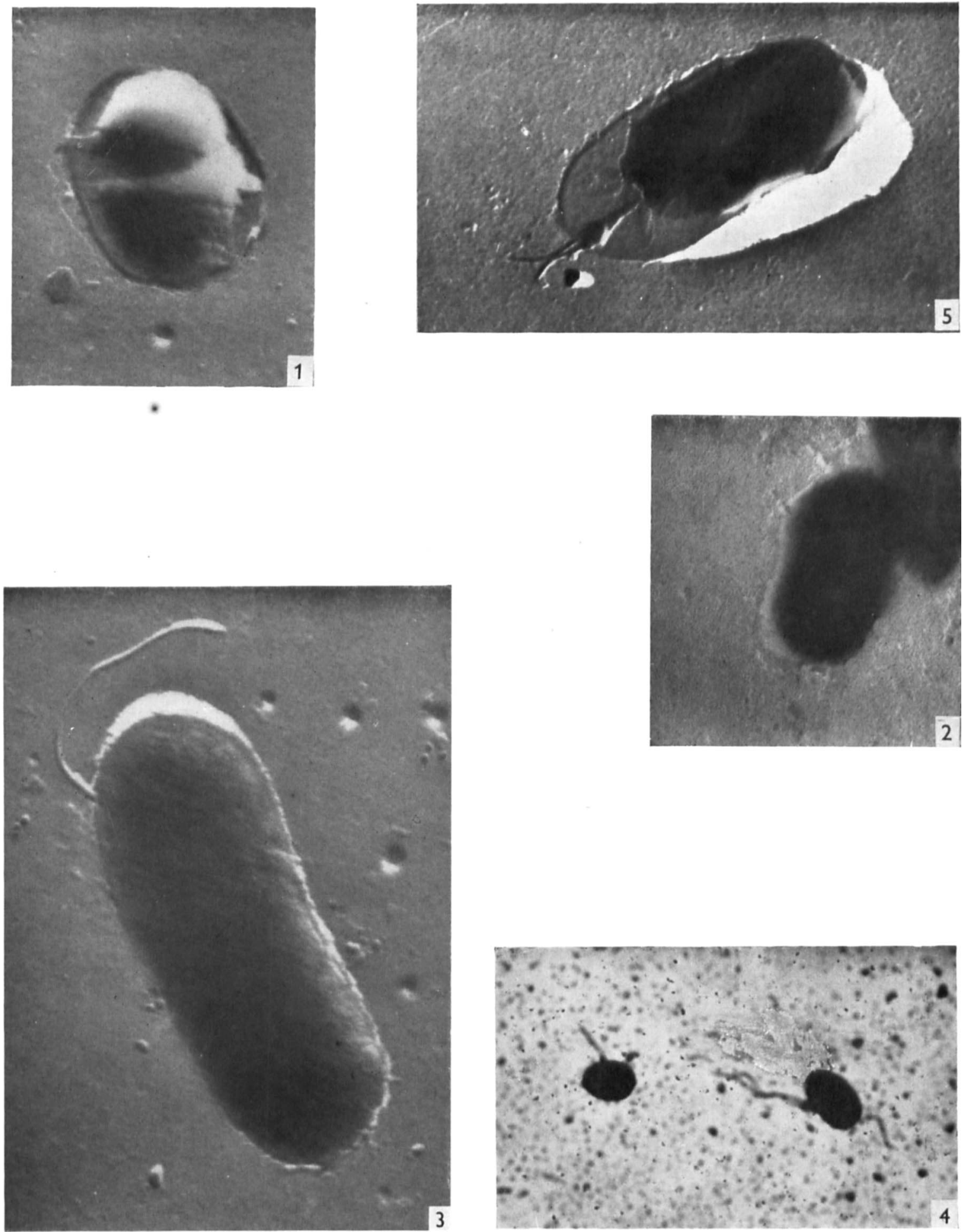

Figs. 1-5

K. A. Bisset and C. M. F. Hale-Flagella of germinating microcysts. Plate 1 
Journal of General Microbiology, Vol. 5, No. 1
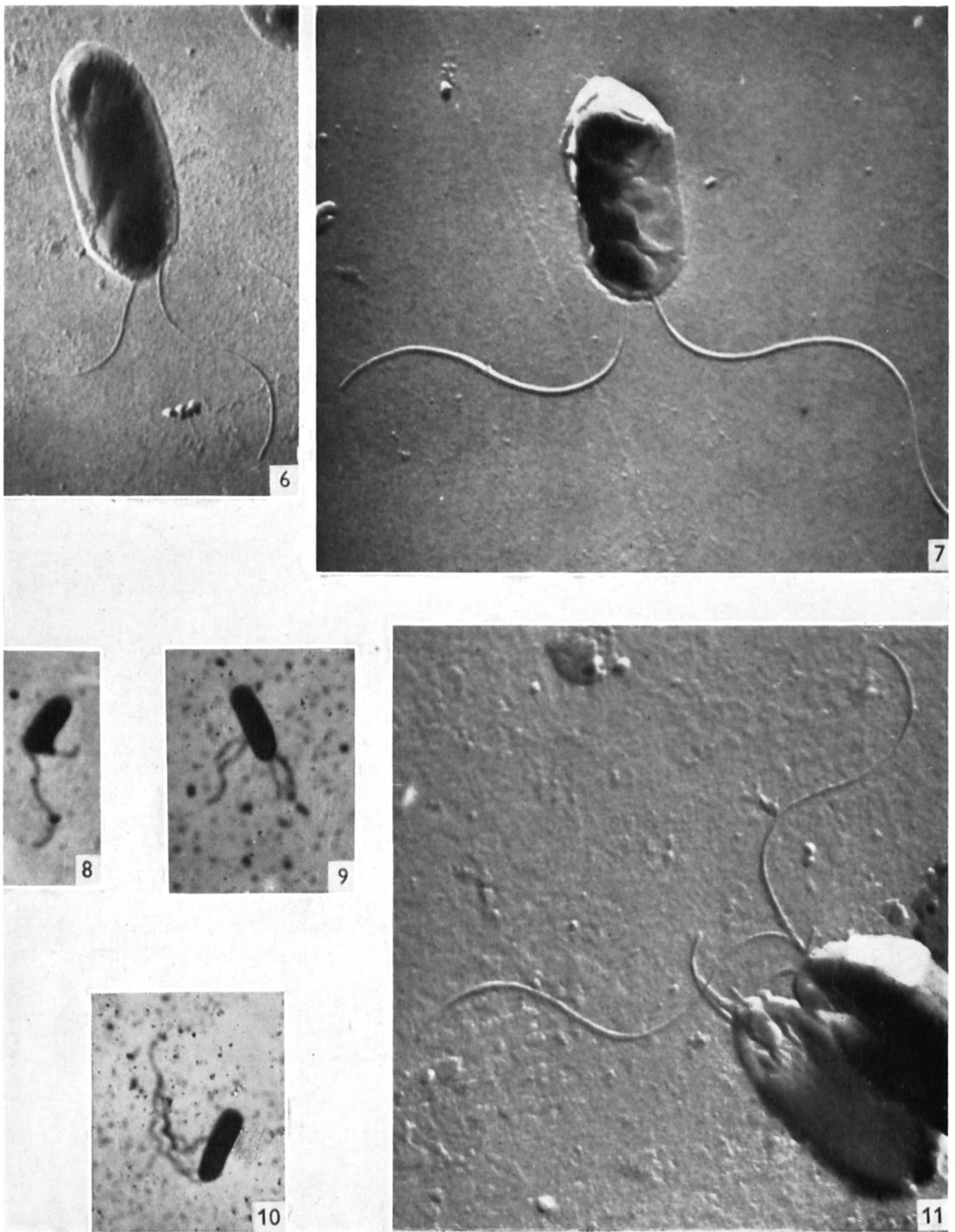

Figs. 6-11

K. A. Bisset and C. M. F. Hale-Flagella of germinating Microcysts. Plate 2 
Journal of General Microbiology, Vol. 5, No. 1
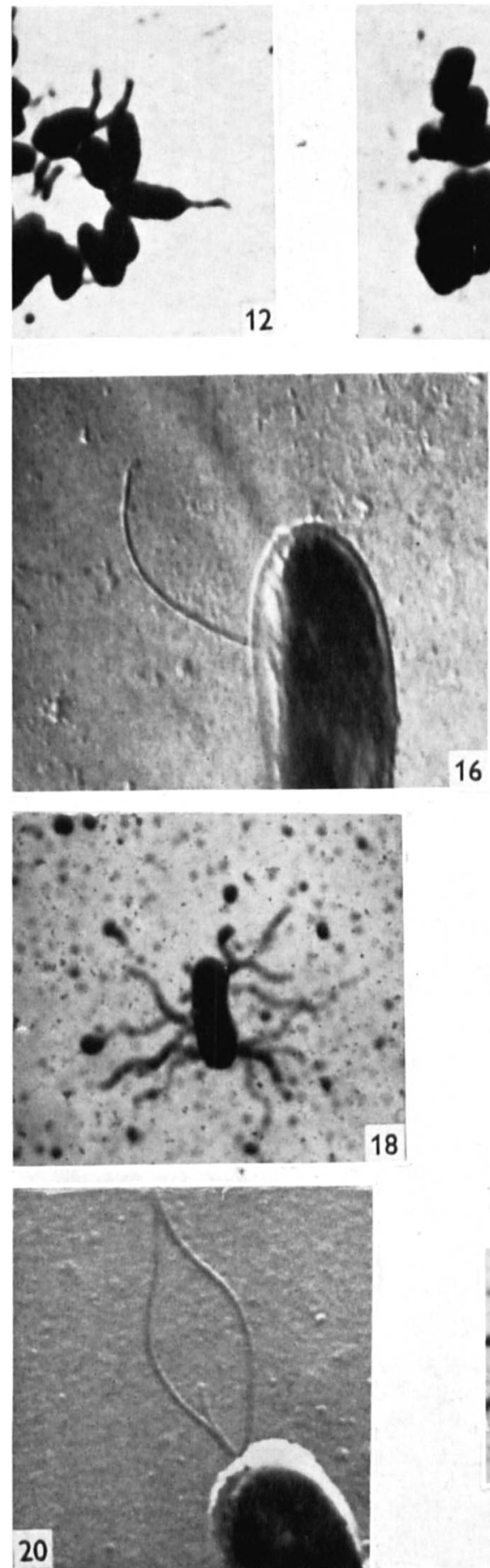

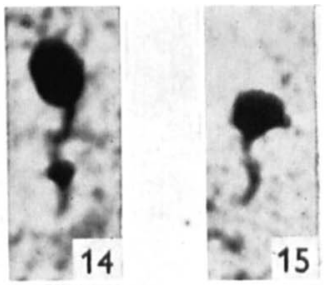

13
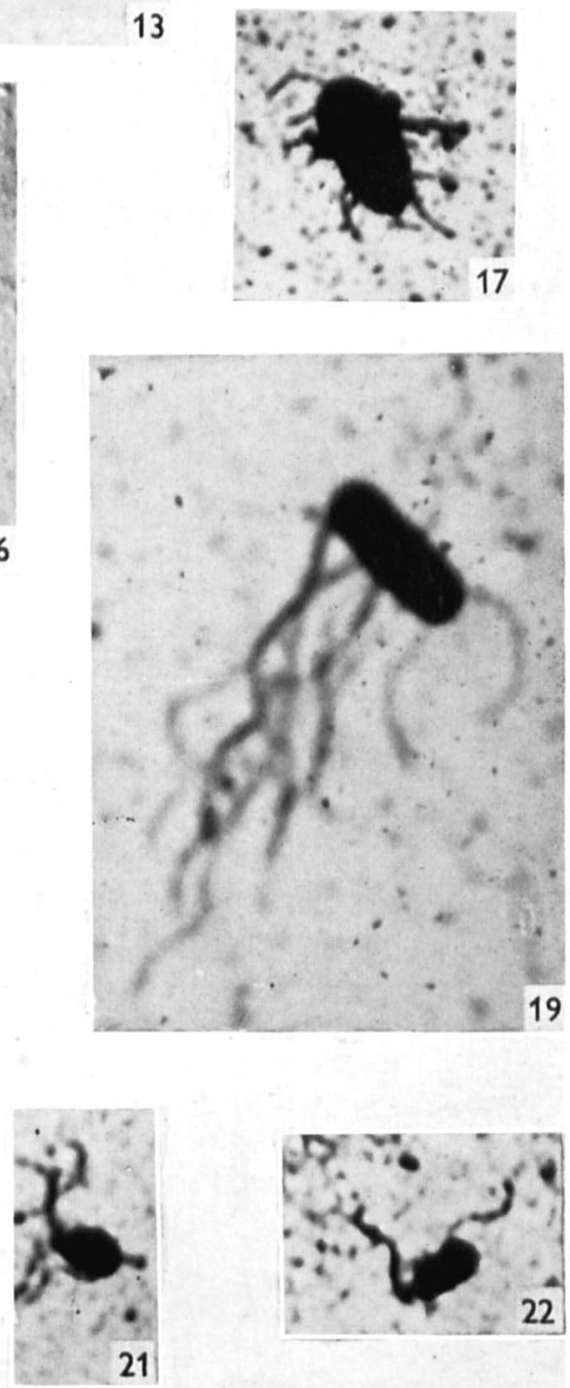

Figs. 12-22

K. A. Bisset and C. M. F. Hale-Flagella of germinating microcysts. Plate 3 
Journal of General Microbiology, Vol. 5, No. 1
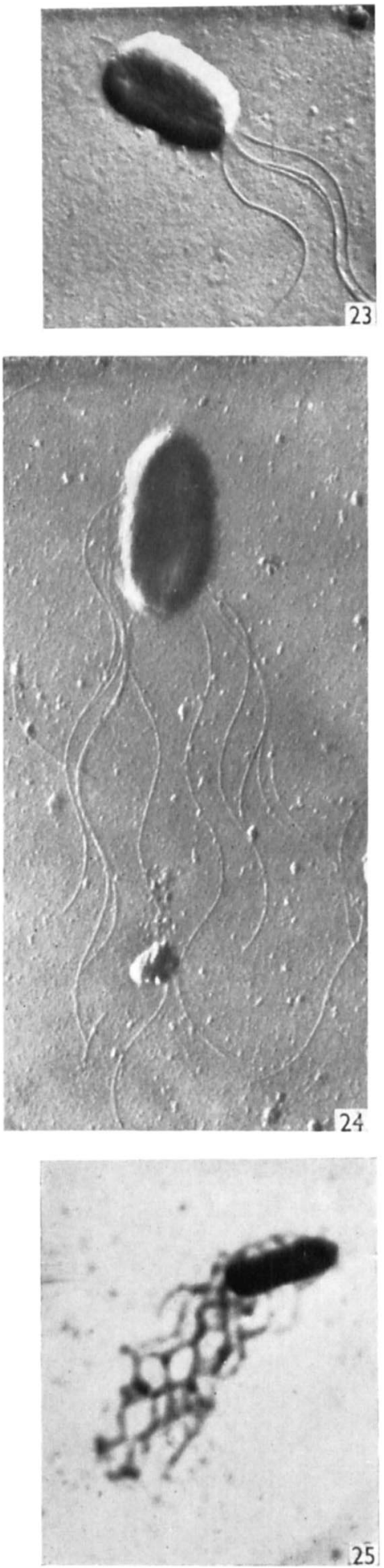
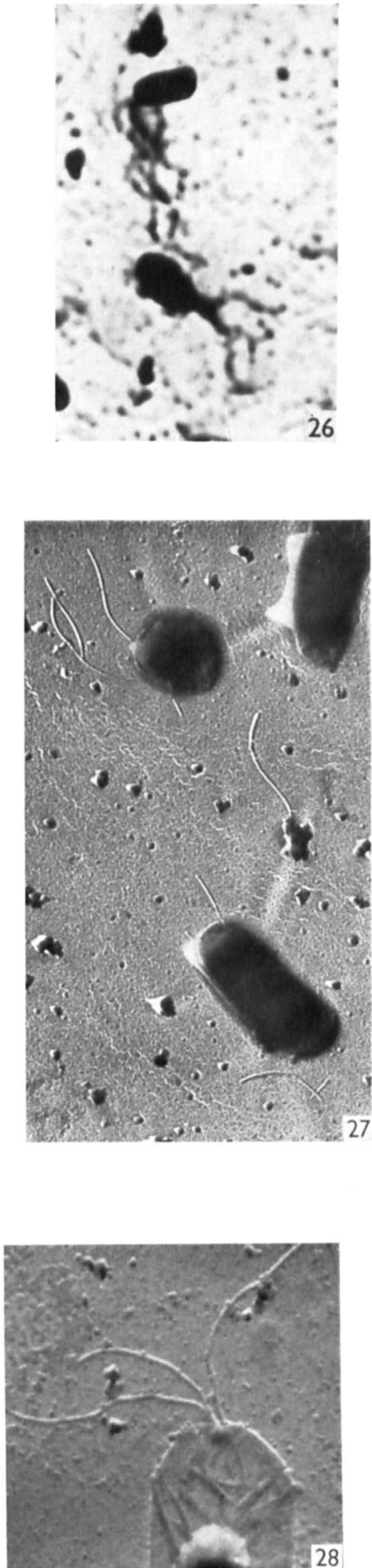

Figs. 23-28

K. A. Bisset and C. M. F. Hale-Flagella of germinating microcysts. Plate 4 


\section{REFERENCES}

Bisset, K. A. (1950a). The Cytology and Life-History of Bacteria. Edinburgh: Livingstone.

BISSET, K. A. (1950b). The differentiation of certain species of Bacteriaceae by the morphology of the microcyst stage. J. gen. Microbiol. 4, 413 .

Bisset, K. A. (1951). The development of the surface structures in dividing bacteria. J. gen. Microbiol. 5, 155.

Houwink, A. L. \& van Iterson, W. (1950). Electron microscopical observations on bacterial cytology. II. A study on flagellation. Biochim. Biophys. Acta, 5, 10.

PiJPer, A. (1946). Shape and motility of bacteria. J. Path. Bact. 58, 325.

Symposium (1949). The Nature of the Bacterial Surface. Oxford: Blackwell.

\section{EXPLANATION OF PLATES}

(The electron micrographs in this study were made with the assistance of Mr C. C. Newton)

\section{Plate 1}

Fig. 1. Salm. typhi, microcyst, showing total absence of flagella. Electron micrograph, gold-shadowed. $\times \mathbf{3 0 , 0 0 0}$.

Fig. 2. Pr. vulgaris, germinating microcyst, showing two sub-polar flagella emerging from the cell wall. Note the appearance of collars. Electron micrograph, gold-shadowed. $\times \mathbf{1 6 , 0 0 0}$. (See also Fig. 1, which is traced from this micrograph.)

Fig. 3. Salm. typhi, germinating microcyst. One sub-polar flagellum is partly grown, and the base is surrounded by a collar. Other flagella are commencing to emerge. Electron micrograph, gold-shadowed. $\times 27,000$. (See also Fig. 2, tracing.)

Fig. 4. As fig. 3, silver impregnation. $\times 3000$.

Fig. 5. Bact. coli, germinating microcyst. Two polar flagella are just emerging through the cell wall. A basal structure (blepharoplast?) is seen. Electron micrograph, goldshadowed. $\times \mathbf{2 0 , 0 0 0}$.

\section{Plate 2}

Figs. 6, 7. As fig. 5, polar flagella further developed. Electron micrograph. $\times 16,000$.

Fig. 8. Pr. vulgaris, germinating microcysts with short, developing flagella. Silver impregnation. $\times 3000$.

Figs. 9, 10. Salm. typhi, young vegetative cells with developing, sub-polar flagella. Silver impregnation. $\times \mathbf{3 0 0 0}$.

Fig. 11. Ps. fluorescens, germinating microcysts showing emergent flagella. Electron micrograph, gold-shadowed. $\times 16,000$.

\section{Plate 3}

Figs. 12-15. Ps. fluorescens, germinating microcysts showing developing flagella. Silver impregnation. $\times \mathbf{3 0 0 0}$.

Fig. 16. Bact. coli, young vegetative cell with growing lateral flagellum. Electron micrograph, gold-shadowed. $\times 16,000$.

Figs. 17-19. Salm. typhi, young vegetative cells showing developing flagella. Silver impregnation. Figs. 17, $18 \times 3000$; fig. $19 \times 5000$.

Fig. 20. Ps. fuorescens, young vegetative cell with developing flagella. Electron micrograph, gold-shadowed. $\times 16,000$.

Figs. 21, 22. Ps. fluorescens, young vegetative cells with emergent flagella at opposite pole. Silver impregnation. $\times 3000$.

\section{Plate 4}

Fig. 23. As figs. 21 and 22, electron micrograph, gold-shadowed. $\times 9,000$.

Fig. 24. Salm. typhi, cell with fully developed flagella in characteristic arrangement. Electron micrograph, gold-shadowed. $\times \mathbf{9 , 0 0 0}$. 
Fig. 25. As fig. 24, silver impregnation. $\times 4,000$.

Fig. 26. Ps. fluorescens, cells with fully developed flagella. Silver impregnation. $\times 3000$.

Fig. 27. Salm. typhi, maturing microcysts and senescent vegetative cells, showing cast-off and broken flagella. Electron micrograph, gold-shadowed. $\times 9,000$.

Fig. 28. Ps. fluorescens, wall of partially disrupted cell, showing a group of basal granules (blepharoplasts?) at the bases of the flagella. Electron micrograph, gold-shadowed. $\times 12,000$.

(Received 11 April 1950) 